\title{
Maintenance culture medium and inoculum based on peach palm leaves for Pleurotus spp. production
}

\author{
Meio de manutenção e inóculo a partir \\ de folhas de pupunheira para a produção de Pleurotus spp.
}

\author{
Elisabeth Wisbeck ${ }^{1 *}$, Endi Pricila Alves ${ }^{1}$, Styfanie Gonçalves de Lima', \\ Regina Maria Miranda Gern', Marcia Luciane Lange Silveira', Sandra Aparecida Furlan'
}

\begin{abstract}
This study evaluated the use of immersion water from peach palm leaves (PPLDA) as a component of the culture medium for the maintenance of Pleurotus spp. and the use of agricultural waste, peach palm leaves, as inoculum support for the fungi. The performance of the inoculum based on peach palm leaves (PPL) for the production of Pleurotus spp. fruiting bodies was compared with that using wheat grains (WG) as inoculum support. PPLDA culture medium (immersion water of peach palm leaves, dextrose, and agar) showed a lower radial velocity of mycelial growth for both fungi than that obtained with the culture medium WDA (wheat extract, dextrose and agar), commonly used as maintenance medium for Pleurotus spp. However, the type of inoculum support does not significantly influence the linear velocity of $P$. ostreatus mycelial growth, reaching $6.71 \mathrm{~mm} /$ day on wheat grains and $6.18 \mathrm{~mm} /$ day on peach palm leaves. Thus, when the inoculum based on peach palm leaves is utilized, the immersion water used for preparing this support can be used for preparing the PPLDA maintenance culture medium, diminishing the production costs of Pleurotus mushrooms. Data also showed that when Pleurotus sajor-caju was cultivated on peach palm leaves, using PPL as inoculum support, the fruiting bodies production parameters $(\mathrm{Y}=47 \%, \mathrm{BE}=3 \%$ and $\mathrm{Pr}=0.2 \mathrm{~g} /$ day $)$ did not differ from that obtained using WG.
\end{abstract}

KEYWORDS: Pleurotus sajor-caju; Pleurotus ostreatus; agricultural waste.
RESUMO: Este trabalho avaliou a utilização da água de imersão das folhas de pupunheira como componente do meio de cultivo para manutenção da cepa fúngica e a produção de inóculo de Pleurotus spp. utilizando como suporte folhas de pupunheira, um resíduo agrícola. Ainda, para verificar a capacidade do inóculo à base de folhas de pupunheira (FP) de produzir corpos frutíferos, foi realizado um experimento comparando FP com o inóculo à base de gráos de trigo (GT). Para tanto, realizou-se a comparaçáo das velocidades de crescimento radial entre o meio de cultivo TDA (extrato de trigo, dextrose e ágar) utilizado para a manutenção de fungos do gênero Pleurotus e o meio FPDA (água de imersão de folhas de pupunheira, dextrose e ágar), e a comparação das velocidades de crescimento linear entre os grãos de trigo, utilizados como suporte para o inóculo de fungos do gênero Pleurotus e as folhas de pupunheira. O meio de cultivo TDA apresentou velocidade radial superior ao meio FPDA para as duas espécies, no entanto, o tipo de suporte não influenciou significativamente a velocidade de crescimento linear de $P$. ostreatus, que apresentou $6,71 \mathrm{~mm} / \mathrm{dia}$ em gráos de trigo e $6,18 \mathrm{~mm} /$ dia em folhas de pupunheira. Assim, quando o inóculo à base de folhas de pupunheira é utilizado, a água de imersão deste suporte pode ser aproveitada para a confecçáo do meio de cultivo de manutenção (FPDA), diminuindo os custos produção. Observou-se que Pleurotus sajor-caju, quando cultivado em folhas de pupunheira utilizando inóculo FP, apresentou cerca de $47 \%$ de rendimento, $3 \%$ de eficiência biológica e $0,2 \mathrm{~g}$ /dia de produtividade, sem diferença significativa com o inóculo GT.

PALAVRAS-CHAVE: Pleurotus sajor-caju, Pleurotus ostreatus, resíduos agrícolas 


\section{INTRODUCTION}

Brazil is the largest producer, consumer, and exporter of hearts of palm in the world. In 2014, the production was 146,279 tons, with 22,954 tons produced in the south of Brazil (IBGE, 2016). Due to the depletion of natural reserves of Juçara palms (Euterpe edulis) generated by severe devastation, the cultivation of alternative palm trees, such as peach palms (Bactris gasipaes) for hearts of palm production has increased in the Southern and Central areas of the country (Снaimsonn; Durigan, 2004). Factors that encourage peach palm cultivation are that the cultivation is high density (5000-6600 plants/ha), occupying a smaller geographical area (Bovi, 2000); it can be grown in several agro-bioclimatic regions (SANTOS et al., 2008); and it can be harvested earlier (around 2 years) than the Juçara species (7 years) (CHAimsohn, 2000).

The cultivation and extraction of hearts of palm generate large amounts of waste and only a small part of the biomass is commercialized in the form of pickled and bottled hearts of palm. Most of the residual biomass remains in the soil after extraction (Soto et al., 2005). According to IsRAel (2005), in order to obtain the heart of palm, it is necessary to cut down the palm tree and remove the fibrous leaves that cover its sheath. Only $1 \mathrm{~m}$ of a palm tree with an approximate height of $15 \mathrm{~m}$ is commercially exploited. In the industrial processing of preserved hearts of palm, the palm tree arrives with coated sheaths with an average weight of $5 \mathrm{~kg}$, of which approximately $95 \%$ is considered waste (SEBEN et al., 2012). The leaves, the stem, and the outer sheaths are discarded in the farming area, and the middle sheaths are discarded in the industrial processing (IsRael, 2005). The permanence of this residue in the soil encourages the humidification process, mobilizing intense microbial activity and temporarily causing a nitrogen deficiency, which is consumed by microorganisms at the expense of plants (ReIcher, 2009). One way to reduce this environmental impact is reusing the waste generated from this process as a substrate for the production of edible mushrooms, providing the opportunity of another source of income for farmers (Philippoussis, 2009). The use of such waste in mushroom production can utilized due to the fact that some fungi are able to decompose lignocellulosic residues. This is the case of fungi of the genus Pleurotus, from the Basidiomycetes class, which, along with other fungi, form a group called "white rot fungi", because they form a white mycelium and have a single lignocellulolitic enzyme complex, with enzymes such as cellulase, ligninase, cellubiase, hemicellulases, and laccase, that degrade lignin as much as cellulose (Carvalho et al., 2010). According to KaKon et al. (2012), mushrooms of the genus Pleurotus have high gastronomic value, are rich in protein and vitamins, contain fiber, carbohydrates and several minerals, and are low in fat.

The cultivation of Pleurotus in its solid state involves two steps. The first step is the introduction of inoculum in the substrate in order to enable mycelial growth through cell division. In the second step, the formation of fruiting bodies occurs (Chang; Miles, 2004). The use of agricultural waste as solid substrate for mushroom cultivation requires the preparation of the substrate. First, the waste must be ground into particles of $2 \mathrm{~cm}$ to $5 \mathrm{~cm}$, immersed in water for about $12 \mathrm{~h}$, placed in polypropylene bags, and sterilized at $121^{\circ} \mathrm{C}$ for $1 \mathrm{~h}$ (BonatTi et al., 2004). The purpose of the trituration of the substrate is the formation of a system of pores in order to facilitate gas exchange and temperature control. The immersion of the substrate in water is important for solubilizing many compounds that can inhibit the mycelial growth (Chang; Miles, 2004). This process generates the immersion water as more waste. The solid inoculum, or "spawn", comprises a solid support such as grains from rye, rice, wheat, millet, and sorghum (CHANG; Miles, 2004), inoculated under aseptic conditions with an agar disk containing the mycelium (BonATTI et al., 2004).

Given the above, this study evaluated the use of the immersion water of the substrate as a component of the culture medium for the maintenance of fungal strain in Petri dishes, and the production of inoculum of Pleurotus spp. using peach palm leaves as growing support. In order to check the capacity of the inoculum based on peach palm leaves (PPL) to produce fruiting bodies, an experiment was conducted comparing this inoculum with that based on wheat grains (WG), generally used in solid state cultivation of Pleurotus.

\section{MATERIAL AND METHODS}

\section{Microorganisms}

Pleurotus sajor-caju was purchased from the Culture Collection of Basidiomycetes of the Instituto de Botânica de São Paulo, under the code CCB 019. Pleurotus ostreatus was purchased from "Deutsche Sammlung von Mikroorganismen und Zellkuturen Gmbh" under the code DSM 1833. The strains were maintained in WDA (Wheat extract, Dextrose, and Agar) (Furlan et al., 1997) and under refrigeration $\left(4^{\circ} \mathrm{C}\right)$.

WDA culture medium was composed of $20 \mathrm{~g} / \mathrm{L}$ of dextrose and $15 \mathrm{~g} / \mathrm{L}$ of agar dissolved in wheat extract (wheat grains boiled in water, $1: 2(\mathrm{w} / \mathrm{v})$, for $10 \mathrm{~min})$. The culture medium was disposed in Duran flasks and sterilized in autoclave at $121^{\circ} \mathrm{C}(1 \mathrm{~atm})$, for 20 minutes. After the temperature cooled to around $40^{\circ} \mathrm{C}, 20 \mathrm{~mL}$ of the culture medium were poured into previously sterilized Petri dishes measuring $90 \mathrm{~mm} \phi \times 15 \mathrm{~mm}$ high. After medium solidification, the center of each Petri dish was inoculated with a $12 \mathrm{~mm}$ agar disk containing fungal mycelium. The fungus was incubated at $28 \pm 2^{\circ} \mathrm{C}$ until the Petri dish was completed covered by the mycelium. 


\section{Utilization of the immersion water in the composition of the maintenance culture medium}

Peach palm leaves were dried at $60^{\circ} \mathrm{C}$ for $24 \mathrm{~h}$, ground in a feed crusher, packed in a raffia bag, and immersed in water for $12 \mathrm{~h}(1: 6 \mathrm{w} / \mathrm{v})$. The leaves were removed and the residual immersion water was added to $20 \mathrm{~g} / \mathrm{L}$ of dextrose and $15 \mathrm{~g} / \mathrm{L}$ of agar, generating the PPLDA (immersion water of peach palm leaves, dextrose, and agar). The culture medium was autoclaved at $121^{\circ} \mathrm{C}(1 \mathrm{~atm})$, for $15 \mathrm{~min}$. Petri dishes prepared with WDA culture medium, widely reported as a maintenance culture medium for Pleurotus strains (FurLan et al., 1997; Bonatti et al., 2004; Rampinelli et al., 2010; Borges et al., 2013) were used as a control.

Petri dishes containing WDA and PPLDA were divided into four quadrants and inoculated, at their center, with an agar disk of $12 \mathrm{~mm}$ diameter containing seven-day-old mycelium of Pleurotus sajor-caju CCB 019 or of Pleurotus ostreatus DSM 1833. The Petri dishes were incubated at $28 \pm 2^{\circ} \mathrm{C}$. The growth advance of the mycelium (in millimeters) was measured daily in each quadrant and the radial growth velocity was calculated by the relation between fungal mycelium growth $(\mathrm{mm})$ and time (days). The experiment was conducted in five replicates.

\section{Utilization of peach palm leaves for inoculum production}

Peach palm leaves were dried at $60^{\circ} \mathrm{C}$ for $24 \mathrm{~h}$, ground in a feed crusher, packed in a raffia bag, and immersed in water for $12 \mathrm{~h}(1: 6 \mathrm{w} / \mathrm{v})$. The leaves were removed, drained until reaching about 70\% humidity (MADAN et al., 1987), and disposed in glass tubes $(1.5 \mathrm{~cm}$ diameter and $15 \mathrm{~cm}$ length) sealed with cotton wool covered with gauze. The tubes were autoclaved at $121^{\circ} \mathrm{C}(1 \mathrm{~atm})$ for $1 \mathrm{~h}$ and inoculated in a laminar flow cabinet pressing the edge of the glass tube on the agar of a Petri dish containing fungal mycelium. This procedure allowed the insertion of a $15 \mathrm{~mm}$ diameter agar disk at the end of the tube. The tubes were incubated at $28 \pm 2^{\circ} \mathrm{C}$ and the linear growth of the mycelium was monitored through the measurement of the daily advance (in millimeters) of the mycelium. The radial growth velocity was calculated by the relation between fungal growth $(\mathrm{mm})$ and time (days). The experiment was conducted in five replicates. In addition, an assay using wheat grains instead of peach palm leaves as growth support was used as a control. The wheat grains were washed and boiled in water $(1: 2, \mathrm{w} / \mathrm{v})$ for $10 \mathrm{~min}$. The water was drained and the cooked grains were added to $\mathrm{CaCO}_{3}$ and $\mathrm{CaSO}_{4}$ at ratios of $0.35 \%$ and $1.3 \%$, respectively, relative to the mass of grains before boiling. This procedure aimed to keep the $\mathrm{pH}$ slightly alkaline and the grains unpacked (BONATTI et al., 2004). The addition of these components to the peach palm leaves was not necessary.

\section{Performance of the peach palm leaves inoculum on production of Pleurotus spp. fruiting bodies}

The cooked grains and the peach palm leaves after immersion were packed in polypropylene bags ( $250 \mathrm{~g}$ dry mass $/ \mathrm{bag}$ ). $\mathrm{CaCO}_{3}$ and $\mathrm{CaSO}_{4}$ were added to the wheat grains in ratios of $0.35 \%$ and $1.3 \%$, respectively, related to the mass of grains after cooking. The bags were sealed and sterilized in autoclave at $121^{\circ} \mathrm{C}(1 \mathrm{~atm})$ for $1 \mathrm{~h}$. After cooling, each bag was inoculated with 3 agar disks of $12 \mathrm{~mm}$ in diameter containing fungal mycelium grown in WDA medium (for wheat grains support) or PPLDA (for peach palm leaves support). All bags were incubated at $28 \pm 2^{\circ} \mathrm{C}$, in the absence of light, until complete colonization of the support.

For substrate preparation, the peach palm leaves were ground in a feed crusher, dried at $60^{\circ}$ for $1 \mathrm{~h}$, and packed in raffia bags. The bags were immersed in water for $12 \mathrm{~h}$. Afterwards, the leaves were removed and drained for about $2 \mathrm{~h}$ until reaching about $70 \%$ moisture (MADAN et al., 1987). The drained leaves were added to $5 \%$ (dry weight) rice bran and packed in polypropylene bags in an amount corresponding to $150 \mathrm{~g}$ of dry weight. The bags were sterilized in autoclave at $121^{\circ} \mathrm{C}(1 \mathrm{~atm})$ for 2 hours and the inoculation was done in laminar flow cabinet using $10 \%$ of inoculum, considering the dry weight of the substrate. The inoculum consisted of palm peach leaves (PPL) or wheat grains (WG) colonized with the mycelium of $P$. ostreatus or P. sajor-caju. The incubation occurred in the absence of light, at $28^{\circ} \mathrm{C}$, until complete substrate colonization. Fruiting bodies induction was achieved by plastic bag perforation and incubation under controlled temperature $\left(28 \pm 2^{\circ} \mathrm{C}\right)$, relative air humidity $(90 \pm 2 \%)$, and light (12 hours/day). The harvest moment was determined visually, when the edge of the pileus was planar, in a stage that precedes the sporulation (Fig. 1). The fruiting bodies were harvested with a scalpel, weighted, dried at $40^{\circ} \mathrm{C}$ for 24 hours in a forced air circulating oven and weighted again for moisture content determination (BONATTI et al., 2004).

The experiments were implemented in seven replicates and were evaluated in terms of yield (Y\%: ratio between fresh fruiting bodies and initial substrate weights), biological efficiency (BE\%: ratio between dried fruiting bodies and initial substrate weights), and productivity $(\operatorname{Pr}(\mathrm{g} /$ day): ratio between dried fruiting bodies weight and total time of cultivation) (HoLtz et al., 2009).
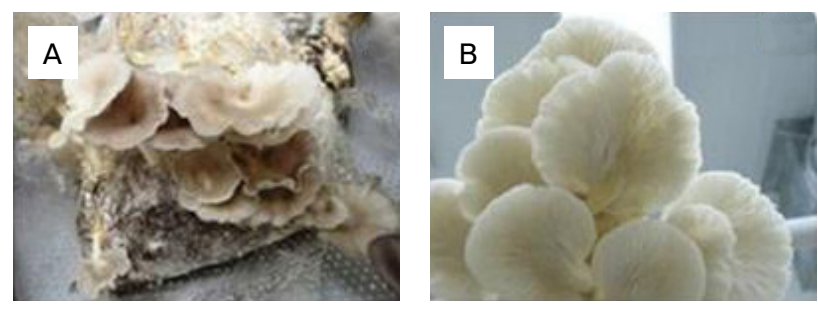

Figure 1. Harvest moment of fruiting bodies of Pleurotus sajor-caju (A) and Pleurotus ostreatus (B). 


\section{Statistical Analysis}

All the data were analyzed throughout the test to reject deviant values (Dixon's Q Test) (Rorabacher, 1991) and were submitted to the variance analysis through the Tukey Test, with a 95\% confidence level (ANOVA).

\section{RESULTS AND DISCUSSION}

\section{Evaluation of immersion water in the composition of the maintenance culture medium}

Full colonization of the Petri dishes containing WDA maintenance culture medium occurred in 5 days for $P$ sajor caju and $P$. ostreatus, with a significantly higher radial velocity of growth $(\mathrm{mm} /$ day) than that obtained with PPLDA (Fig. 2). When PPLDA was used, full colonization of the Petri dishes occurred in 7 and 6 days for P. sajor-caju and P. ostreatus, respectively. Figure 3 shows the visual aspect of the Petri dishes colonized by the mycelium.

Visual analysis shows that mycelium growth of $P$. ostreatus is more vigorous when cultivated in PPLDA than in WDA (Fig. 3B), suggesting that PPLDA is more nutritious for this species. P. sajor-caju has grown better in WDA (Fig. 3A). Pedra; Marino (2006) found that the vigorous growth of the mycelium can be influenced by the substrate composition. However, in our research, the vigor of the mycelium was not reflected in the radial growth velocity since the growth was slower in PPLDA than in WDA (Fig. 2), regardless of the

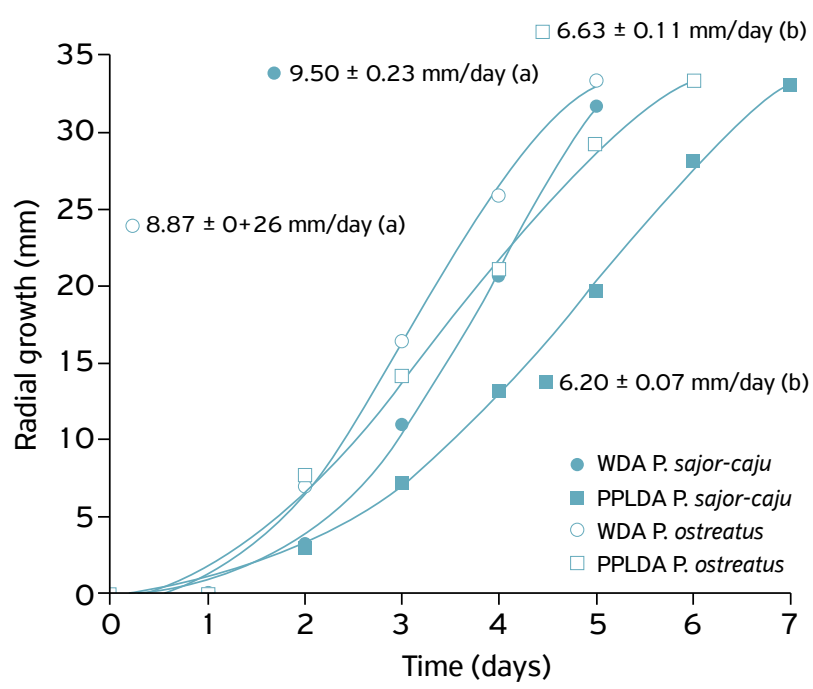

Figure 2. Rate of radial growth $(\mathrm{mm})$ with time (days) and radial velocity of growth ( $\mathrm{V}_{\mathrm{R}} \pm$ standard deviation) of Pleurotus sajor-caju and Pleurotus ostreatus in WDA (wheat extract, dextrose and agar) and PPLDA (immersion water of peach palm leaves, dextrose and agar). Equal letters mean values without significant differences based on Tukey Test, with 95\% confidence level (ANOVA). mycelium vigor. BERnARDi et al. (2007) also observed that $P$. ostreatoroseus growing in rice husks showed bigger mycelium growth regardless of the lesser vigor visually shown by the lesser density of the hyphae.

FAN et al. (2001) reported values for mycelial velocity of $8.98 \mathrm{~mm} /$ day and $8.12 \mathrm{~mm} /$ day for $P$. sajor-caju LPB 20 and P. sajor-caju LPB 19, respectively, both grown in medium containing coffee husks extract, dextrose, and agar. These velocities are similar to those found in our research using wheat grains.

Donini et al. (2005) found values of radial growth of $P$. ostreatus BF24 of 24.1, 17.3, $17.8 \mathrm{~mm} /$ day, and $10.7 \mathrm{~mm} /$ day when cultivated in an infusion of elephant grass, soybean straw, sugar cane, or corn cob in boiling water for $30 \mathrm{~min}$ added to $10 \mathrm{~g} / \mathrm{L}$ of dextrose, respectively. Sales-Campos et al. (2011) using culture media composed of the infusion of marupá straw and açaí seeds in boiling water for $30 \mathrm{~min}$ added to bran cereals, $\mathrm{CaCO}_{3}$ and $12 \mathrm{~g} / \mathrm{L}$ of dextrose, reported radial growth of $P$. ostreatus of $81 \mathrm{~mm}$ in 7 days, reaching $11.6 \mathrm{~mm} /$ day of radial growth velocity. CARvalHo et al. (2013) evaluated the mycelial growth of $P$. ostreatus in culture media containing $80 \%$ leaves from different banana cultivars supplemented with $20 \%$ wheat bran, and boiled for $15 \mathrm{~min}$. The authors reported velocity values ranging from 12.00 to $13.75 \mathrm{~mm} /$ day.

The values of radial velocity reported in other scientific sources are higher than those found in this body of work using PPLDA. It should be noted that during the immersion of the leaves and the cooking of the residues and the grains, several compounds are solubilized (CHANG; Miles, 2004), becoming available for the maintenance of the microorganisms. The results reported in this study and in other sources show that the type

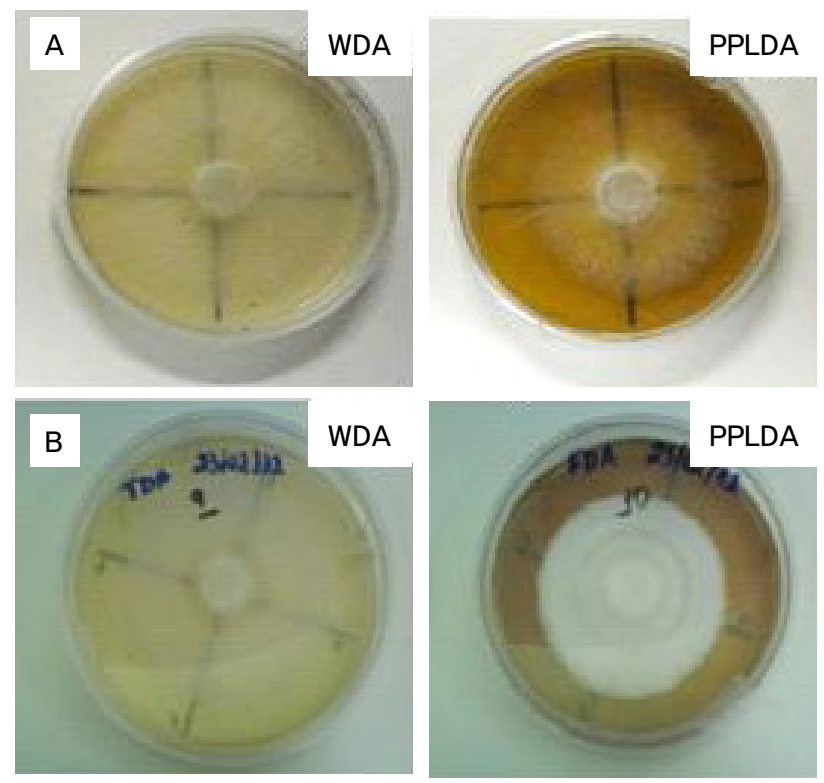

Figure 3. Radial growth of the mycelium of Pleurotus sajor-caju (A) and Pleurotus ostreatus (B) in WDA (wheat extract, dextrose, and agar) and PPLDA (immersion water of peach palm leaves, dextrose, and agar). 
of substrate utilized for preparing the culture medium, the kind of treatment of the substrate and the fungal strain, have direct influence on the mycelial growth velocity. Despite taking a few more days to complete the colonization of the Petri dish, the PPLDA culture medium composed of peach palm immersion water, instead of the wheat extract (more expensive) utilized for preparing WDA, (Fig. 2), is still viable as a maintenance culture medium for $P$. sajor-caju and $P$. ostreatus.

\section{Evaluation of the inoculum production}

The values of mycelial linear growth ( $\mathrm{mm} /$ day) on the analyzed substrates (wheat grains and peach palm leaves) for P. sajor-caju and P. ostreatus are shown in Figure 4. P. sajor-caju colonized the wheat grains (WG) faster (20 days) than P. ostreatus (27 days). However, there were no significant differences in the linear growth of both species when peach palm leaves (PPL) were used as substrate. Additionally, the type of inoculum support did not significantly influence the linear growth velocity of $P$. ostreatus, which reached $6.71 \mathrm{~mm} /$ day and $6.18 \mathrm{~mm} /$ day in WG and in PPL, respectively.

Donini et al. (2006) reported higher values for linear growth velocity of $P$. ostreatus $\mathrm{BF} 24$ when they evaluated elephant grass (Pennisetum sp.) as the substrate, supplemented with soy, wheat, rice, and corn bran, at concentrations of 0,10 and $20 \%$. The linear growth velocity was $20.9 \mathrm{~mm} /$ day for the experiment executed without supplementation, and this value decreased when the supplementation increased. PALHeTA et al. (2011) evaluated the mycelial linear growth of the strains Pleurotus ostreatus and Pleurotus florida in cupuaçu husks (CC) supplemented with $10 \%$ rice bran (FA) reaching values of $4.0 \mathrm{~mm} /$ day and $3.1 \mathrm{~mm} /$ day for Pleurotus florida and Pleurotus ostreatus,

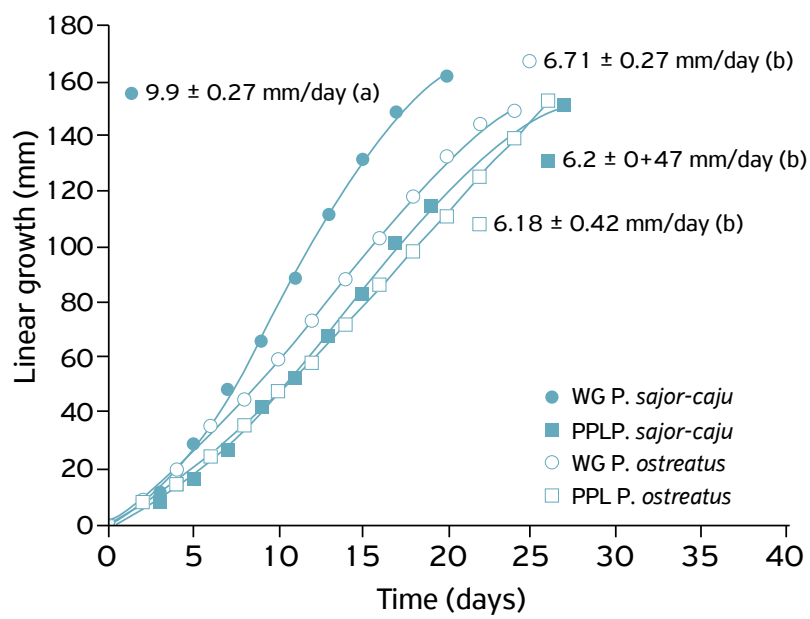

Figure 4. Rate of linear growth ( $\mathrm{mm}$ ) with time (days), and linear velocity of growth ( $\mathrm{V}_{\mathrm{L}} \pm$ standard deviation) of Pleurotus sajor-caju and Pleurotus ostreatus in wheat grains (WG) and in peach palm leaves (PPL). Equal letters mean values without significant differences based on the Tukey Test, with 95\% confidence level (ANOVA). respectively. These values were lower than those achieved in our research, using wheat grains and peach palm leaves.

Figure 5 shows visual aspects of the linear mycelial growth of P. sajor-caju (Fig. 5A) and P. ostreatus (Fig. 5B), in glass tubes containing wheat grains and peach palm leaves.

Greater mycelium vigor, revealed by the greater density of the hyphae (BERNARDI et al., 2007) can be observed for both species grown on wheat grains. However, the greater vigor of the mycelium was not reflected in the linear growth velocity, since no significant differences in velocities achieved in wheat grains and peach palm leaves were observed (Fig. 4).

\section{Performance of the peach palm leaves inoculum on production of Pleurotus spp. fruiting bodies}

Results in terms of yield (Y\%), biological efficiency (BE\%), and productivity $(\mathrm{Pr}-\mathrm{g} /$ day) for cultivation of $P$. sajor-caju and $P$. ostreatus using inoculum based on wheat grains (WG) or in peach palm leaves (PPL) are shown in Table 1.

Table 1 shows that the production parameters did not differ significantly for both fungi when WG or PPL were utilized. According to these results, the inoculum based on peach palm
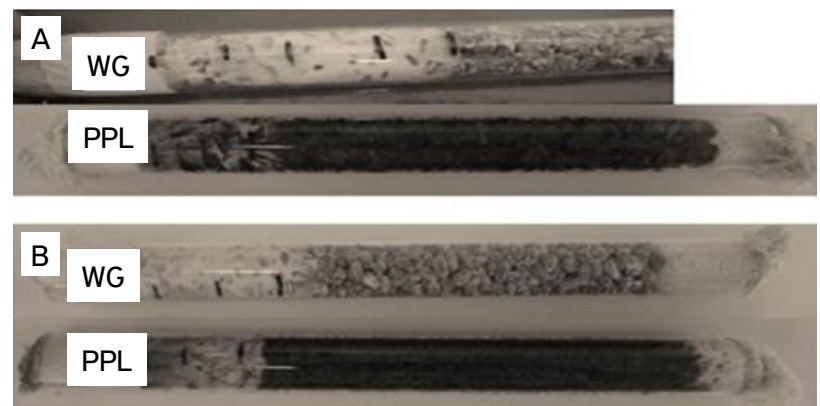

Figure 5. Linear mycelial growth in wheat grains (WG) and in peach palm leaves (PPL) disposed in glass tubes inoculated with Pleurotus sajor-caju (A) and Pleurotus ostreatus (B).

Table 1. Mean values \pm standard deviation of yield (Y\%), biological efficiency (BE\%), and productivity ( $\mathrm{Pr}-\mathrm{g} /$ day) achieved with the cultivation of $P$. sajor-caju and $P$. ostreatus using inoculum based on wheat grains (WG) or peach palm leaves (PPL)

\begin{tabular}{|c|c|c|c|}
\hline Inoculum & $\begin{array}{c}Y \\
(\%)\end{array}$ & $\begin{array}{l}\text { BE } \\
(\%)\end{array}$ & $\begin{array}{c}\operatorname{Pr} \\
\text { (g/day) }\end{array}$ \\
\hline \multicolumn{4}{|c|}{ Pleurotus sajor-caju } \\
\hline WG & $47.7 \pm 7.2 a$ & $3.79 \pm 0.24 c$ & $0.25 \pm 0.02 d$ \\
\hline PPL & $46.3 \pm 6.5 a$ & $3.03 \pm 0.33 c$ & $0.20 \pm 0.02 d$ \\
\hline \multicolumn{4}{|c|}{ Pleurotus ostreatus } \\
\hline WG & $38.6 \pm 14.6 a$ & $3.88 \pm 1.11 c$ & $0.11 \pm 0.03 e$ \\
\hline PPL & $23.3 \pm 10.7 b$ & $2.64 \pm 1.16 c$ & $0.11 \pm 0.05 e$ \\
\hline
\end{tabular}

Equal letters mean values without significant differences based on the Tukey Test, with 95\% confidence level (ANOVA). 
leaves can be suggested as a substitution for the inoculum based on wheat grains. This proposal is based on the fact that peach palm leaves are considered waste and have a low cost of acquisition. Additionally, comparing the two species, $P$. sajor-caju showed higher productivity than $P$. ostreatus $(0.11 \mathrm{~g} /$ day $)$ in both inoculum supports $(0.25 \mathrm{~g} /$ day in WG and $0.20 \mathrm{~g} /$ day in PPL), showing a higher preference for peach palm leaves than $P$. ostreatus. HoLtz et al. (2009) found higher productivity for $P$. ostreatus, about $0.37 \mathrm{~g} /$ day, using cotton waste from the textile industry as substrate. However, the authors used $20 \%$ of inoculum based on wheat grains, instead of $10 \%$ as used in our body of work.

Table 1 also shows that $P$. sajor-caju reached a higher yield than $P$. ostreatus using PPL inoculum. However, the conversion of this value to $\mathrm{BE}$ (considered a more accurate parameter as the ratio between the weight of the fruiting bodies and the weight of the substrate, both without moisture interference) makes that difference disappear.

\section{CONCLUSION}

The maintenance culture medium based on wheat extract (WDA) promoted radial growth velocities greater than that obtained with the culture medium based on immersion water of peach palm leaves (PPLDA) for both fungal species, $P$. sajorcaju and P. ostreatus.

The inoculum based on wheat grains (WG) favors the linear growth velocity for the P. sajor-caju strain.

The immersion water of peach palm leaves can be utilized for the preparation of the fungi maintenance culture medium and also lowers production costs since peach palm leaves are considered agro-industrial waste.

In the evaluation for both fungal species (P sajor-caju and $P$. ostreatus), there is no significant difference in biological efficiency (BE\%) and productivity (Pr g/day) when inoculum based on peach palm leaves or wheat grains are used.

\section{ACKNOWLEDGEMENTS}

Much gratitude is expressed towards the Conselho Nacional de Desenvolvimento Científico e Tecnológico (CNPq), for granting the Scientific Initiation Scholarship (PIBIC/CNPq). The authors would also like to thank the Fundo de Apoio à Pesquisa (FAP) UNIVILLE for the financial support.

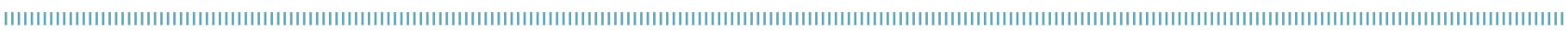
REFERENCES

BERNARDI, E.; DONINI, L.P.; MINOTTO, E.; NASCIMENTO, J.S. Utilização de diferentes substratos para a produção de inóculo de Pleurotus ostreatoroseus Sing. Revista Ciência Agronômica, v.38, n. 1, p.84-89, 2007.

BONATTI, M.; KARNOPP, P.; SOARES, H.M.; FURLAN, S.A. Evaluation of Pleurotus ostreatus and Pleurotus sajor-caju nutritional characteristics when cultivated in different lignocellulosic wastes. Food Chemistry, v.88, n.3, p.425-428, 2004.

BORGES, G.M.; DE BARBA, F.F.M.; SCHIEBELBEIN, A.P.; PEREIRA, B.P.; BONATTI-CHAVES, M.; SILVEIRA, M.L.L.; PINHO, M.S.L.; FURLAN, S.A.; WISBECK, E. Extracellular polysaccharide production by a strain of Pleurotus djamor isolated in the south of Brazil and antitumor activity on Sarcoma 180. Brazilian Journal of Microbiology, v.44, n.4, p. 1059-1065, 2013.

BOVI, M.L.A. O agronegócio palmito de pupunha. O Agronômico, v. 52, n. 1, p. 10-12, 2000.

CARVALHO, C.S.M.; SALES-CAMPOS, C.; ANDRADE, M.C.N. Mushrooms of the Pleurotus genus: A review of cultivation techniques. Interciencia, v.35, n.3, p.177-182, 2010.

CARVALHO, C.S.M.; DEAGUIAR, L.V.B.; SALES-CAMPOS, C.; MINHONI, M.T.A., ANDRADE, M.C.N. Cultivo in vitro de Pleurotus ostreatus em resíduos de bananeira. Ambiência, v.9, n.3, 651-660, 2013.
CHAIMSOHN, F.P. Cultivo de pupunha e produção de palmito. Viçosa: Aprenda Fácil, 2000. $121 \mathrm{p}$.

CHAIMSOHN, F.P.; DURIGAN, M.E. Rentabilidade do Cultivo de Palmeira-Real versus Pupunha para Produção de Palmito. In: Anais do I Encontro Paranaense sobre Palmitos Cultivados: O Agronegócio Pupunha e Palmeira-Real, Pontal do Paraná: Embrapa Florestas, 2004.

CHANG, S.T.; MILES, P.G. Mushrooms: cultivation, nutritional value, medicinal effect and environmental impact. New York: CRC Press, $451 \mathrm{p}, 2004$.

DONINI, L.P.; BERNARDI, E.; MINOTTO, E.; NASCIMENTO, J.S. Desenvolvimento in vitro de Pleurotus spp. sob a influência de diferentes substratos e dextrose. Arquivos do Instituto Biológico, v.72, n.3, p.331-338, 2005.

DONINI, L.P.; BERNARDI, E.; NASCIMENTO, J.S. Colonização do substrato capim-elefante suplementado com farelos por Pleurotus ostereatus. Revista de Biologia e Ciências da Terra, v.6, n.2, p.185-193, 2006.

FAN, L.; SOCCOL, C.R. Detoxificação da casca de café utilizando fungo comestível do gênero Pleurotus. In: II Simpósio de Pesquisa dos Cafés do Brasil, Vitória, ES. Resumos. Brasília, DF: Embrapa Café, p.319-328, 2001. 
FURLAN, S.A.; VIRMOND, L.J.; MIERS, D.A.; BONATTI, M.; GERN, R.M.M.; JONAS, R. Mushrooms strains able to grow at high temperatures and low pH values. World Journal of Microbiology and Biotechnology, v.13, n.6, p.689-692, 1997.

HOLTZ, M.; BORGES, G.M.; FURLAN, A.S.; WISBECK, E. Cultivo de Pleurotus ostreatus utilizando resíduos de algodão da indústria têxtil. Revista de Ciências Ambientais, v.3, n. 1, p.37-51, 2009.

IBGE. Instituto Brasileiro de Geografia e Estatística, Ministério do Planejamento, Orçamento e Gestão (2016) Produção Agrícola Municipal: Culturas temporárias e permanentes, Brasil. Disponível em: <http://biblioteca.ibge.gov.br/visualizacao/periodicos/66/ pam_2014_v41_br.pdf>. Acesso em 11 aug. 2014.

ISRAEL, C.M. Utilização do resíduo do processamento do palmiteiro para a produção de enzimas hidrolíticas por fungos do gênero Polyporus. 2005. 136f. Dissertação (Mestrado em Engenharia Ambiental) - Fundação Universidade Regional de Blumenau, Blumenau, 2005.

KAKON, A.J.; CHOUDHURY, M.B.K.; SAHA, S. Mushroom is an Ideal Food Supplement. Journal of Dhaka National Medical College \& Hospital, v. 18, n.1, p.58-62, 2012.

MADAN, M.; VASUDEVAN, P.; SHARMA, S. Cultivation of Pleurotus sajor-caju on different agro-wastes. Biological Wastes, v.22, n.4, p.241-250, 1987.

PEDRA, W.N.; MARINO, R.H. Cultivo axênico de Pleurotus spp. em serragem da casca de coco (Cocos nucifera Linn.) suplementada com farelo de arroz e/ou de trigo. Arquivos do Instituto Biológico, v.73, n.2, p.219-225, 2006.

PALHETA, R.A.; VIEIRA, J.N.; NEVES, K.C.S.; TEIXEIRA, M.F.S. Crescimento micelial vertical de duas espécies de Pleurotus em resíduo agroindustrial da Amazônia utilizando planejamento fatorial. Caderno de Pesquisa, Série Biologia, v.23, n.3, p.52-60, 2011.
PHILIPPOUSSIS, A.N. Production of mushrooms using agroindustrial residues as substrates. In: Nigam, P.S.; Pandey, A. (Ed.). Biotechnology for agro-industrial residues utilization. New York: Springer, 2009, p.163-196.

RAMPINELLI, J.R.; SILVEIRA, M.L.L.; GERN, R.M.M.; FURLAN, S.A.; NINOW, J.L.; WISBECK, E. Valor nutricional de Pleurotus djamor cultivado em palha de bananeira. Alimentos e Nutrição, v.2 1, n.2, p.197-202, 2010.

REICHER, J.M. SOLOS FLORESTAIS. Apostila Teorica, 2009. Disponível em: <http://www.fisicadosolo.ccr.ufsm.quoos.com.br/ downloads/Disciplinas/SolosFlorestais/Apostila_Teorica\%20SF. pdf >. Acesso em 25 abr. 2014.

RORABACHER, D.B. Statistical treatment for rejection of deviant values: critical values of Dixon's " $Q$ " parameter and related subrange rations at the $95 \%$ confidence level. Analytical Chemistry, v.63, n.2, p.139-146, 1991

SALES-CAMPOS, C.; CARVALHO, C.S.M.; AGUIAR, L.V.B.; ANDRADE, M.C.N. Cinética micelial dos fungos comestíveis Pleurotus ostreatus e Lentinula edodes em resíduos lignocelulósicos. Arquivos do Instituto Biológico, v.78, n.1, p.141-145, 2011.

SANTOS, A.F.; CORRÊA JÚNIOR, C.; NEVES, E.J.M. Palmeiras para produção de palmito: juçara, pupunheira e palmeira real. Colombo: Embrapa Florestas, 2008, 188p.

SEBEN, L.L., DE PAULA, I.C., VIANA, S.G. Análise do processo de beneficiamento da Palmeira Real da Austrália (palmito em conserva) para determinação das variáveis que influenciam as operações de valorização de seus resíduos. Produto \& Produção, v.13, n. 1, p.75-92, 2012

SOTO, G.; LUNA-OREA, P.; WAGGER, M.G.; SMYTH, T.J.; ALVARADO, A. Foliage residue decomposition and nutrient release in peach palm (Bactris gasipaes Kunth) plantations for heart-of-palm production in Costa Rica. Agronomy Journal, v.97, p. 1396-1402, 2005. 